\title{
В.А. Лихошвай: учитель, ученый, собеседник
}

\author{
А.И. Клименко凶
}

Аннотация: Статья, в основу которой положены личный опыт и воспоминания автора, рассказывает о значении В.А. Лихошвая как педагога, одного из основателей Сибирской школы математической биологии, его характере и роли по отношению к студентам.

Ключевые слова: Виталий Александрович Лихошвай; Институт цитологии и генетики СО РАН; Сибирская школа математической биологии; преподавание математической биологии и биоинформатики.

Благодарности: Автор выражает благодарность редакции «Писем в Вавиловский журнал генетики и селекции» за встречный энтузиазм, способствовавший написанию и публикации данной работы.

Для цитирования: Клименко А.И. В.А. Лихошвай: учитель, ученый, собеседник. Письма в Вавиловский журнал генетики и селекции. 2020;6(4):199-200. DOI 10.18699/Letters2020-6-26

\section{V.A. Likhoshvai as an educator, a scientist, an interlocutor}

\author{
A.I. Klimenko $\otimes$
}

Abstract: The article presents a short character sketch dedicated to the credit of V.A. Likhoshvai as an educator, one of the founding figures of the Siberian school of mathematical biology, and describes his academic temper and attitude towards his students. The article is based on the recollections of the personal experience of the author.

Key words: Vitaly A. Likhoshvai; Institute of Cytology and Genetics, SB RAS; Siberian school of mathematical biology; mathematical biology and bioinformatics in higher education.

For citation: Klimenko A.I. V.A. Likhoshvai as an educator, a scientist, an interlocutor. Pisma v Vavilovskii Zhurnal Genetiki i Selektsii = Letters to Vavilov Journal of Genetics and Breeding. 2020;6(4):199-200. DOI 10.18699/Letters2020-6-26 (in Russian)

Мое знакомство с Виталием Александровичем Лихошваем началось в 2012 году, когда я, только поступив в магистратуру факультета естественных наук НГУ, начала посещать его курс по моделированию генных сетей. Несмотря на то что область была довольно новой для меня - ведь я пришла в системную биологию из компьютерных наук меня сразу захватила тематика и, не в последнюю очередь, благодаря лекциям Виталия Александровича, которые он неизменно читал увлеченно и в свойственной ему живой манере. Мало что может сравниться в этом мире с радостью слушать человека, глубоко и искренне погруженного в свою тему, а потому способного рассказывать о ней чистой, ясной речью и с горящими глазами. Таким был В.А. Лихошвай ученым, учителем, собеседником.

В то время в студенческой среде курс Лихошвая слыл предметом хотя и интересным, но местами излишне фундаментальным, уделяющим внимание теоремам и предель- ным основаниям математической биологии как науки. Однако в этом и было сердце подхода, практикуемого Виталием Александровичем - он стремился докопаться до самой сути моделируемых явлений и процессов, чтобы дать им максимально адекватное и твердо обоснованное математическое описание. Он верил, что математическая модель - это не просто полезный феноменологический инструмент, позволяющий экономить деньги и время на проведение экспериментов, но способ познания и осмысления реальности, форма синтеза разрозненных фактов об исследуемых биологических системах в интегрированное научное знание. И эту веру он передавал своим ученикам и ученицам.

Несмотря на то, что курс лекций, которые В.А. Лихошвай читал вместе со своими учениками на кафедре информационной биологии ФЕН НГУ, официально назывался «Математические основы системной биологии I: генные сети: математическое моделирование и анализ», сам Виталий 
Александрович неформально давал ему название «Математическая биология гена». В отличие от тех курсов, которые стремились дать актуальный срез современных исследований в области биоинформатики и системной биологии, курс Лихошвая действительно отличался историчностью, фундаментальностью и стремлением в четкой и ясной форме сформулировать и донести математические основания, на которые опираются используемые в нашей работе методы. Примеры постановки и решения фундаментальных проблем и практических задач, рассмотрение теории генных сетей давали нам образцы плодотворного взаимодействия математической строгости и биологической глубины соответствующих постановок. Благодаря этому курсу у меня и моих сокурсников была воспитана культура исследования молекулярно-генетических систем на основе достойных примеров работ представителей школы В.А. Лихошвая.

Я нередко задерживалась после пар, чтобы поговорить с Виталием Александровичем о волновавших тогда меня вопросах, имеющих отношение к математической биологии и естествознанию вообще. Это было время оживленных бесед на самые разные темы. Бывало, мы спорили, - например, о месте детерминизма в научной картине мира, - но даже в случае разногласий В.А. Лихошвай всегда придерживался интеллектуальной честности и уважения по отношению к собеседнику, проявляя цельность характера независимо от пространства научной дискуссии - будь то защита диссертационной работы или разговор о науке за чашкой чая.

Отдельно хотелось бы сказать о сторонах характера В.А. Лихошвая, которые он проявлял как экзаменатор. Мне не раз доводилось проходить испытания, сидя перед нимкак в рамках его курса, так и сдавая вступительные экзамены в аспирантуру, кандидатский минимум. Виталий Александрович на экзамене любил задавать дополнительные вопросы на понимание предмета и тем самым походил на глубоководного ныряльщика - он всегда пытался «нащупать дно» знаний студента по вопросу, на который тот отвечал, чтобы обозначить на карте ту самую черту понимания, за которой находится уже terra incognita. А такая черта по любому научному вопросу найдется у каждого из нас в силу хотя бы того факта, что за определенным количеством вопросов «Почему...?» и «А как...?» лежит то бездонное пространство океана тайн Природы, куда осторожно, оставляя за собой изведанное, пядь за пядью продвигается самая передовая современная наука. А студент... что студент? Конечно, переживает, конечно, достает из глубин своих знаний все, до последней капли, чтобы потом собрать максимально детальную картину по вопросу и представить ее Виталию Александровичу, который неизменно дополнит парой штрихов, чтобы она обрела некоторую целостность и доставила взаимное интеллектуальное удовольствие экзаменатору и экзаменуемому. Могло казаться, что Лихошвай тем самым вынимает душу, но на деле это развивало способность к самостоятельным рассуждениям и помогало раскрыть ис- тинный потенциал испытуемых, помочь им нащупать точки дальнейшего роста. Лично я благодарна Виталию Александровичу за то, что он наряду с другими редкими преподавателями в моей жизни, подарил мне такой взгляд на возможности, которые открывает пространство экзамена.

Придя в биологический институт из области математики, В.А. Лихошвай всегда имел глубокое почтение к собственно биологии. Как преподаватель и участник научных семинаров, он проявлял это в особом отношении к студентам и аспирантам - выходцам из других базовых дисциплин. Лихошвай говорил, что в то время как биолог может позволить себе вольное обращение с предметной областью и устоявшимися биологическими представлениями, математические биологи, имеющие отличное от биологического базовое образование, должны избегать сенсационности, стоя на твердой почве биологического факта и придерживаясь тщательного подхода к обоснованию своих предположений. Тем самым Виталий Александрович, однако, нисколько не отрицал вклада математической биологии в развитие биологии как науки в целом, но предостерегал молодых математических биологов от чрезмерно вольного и поверхностного обращения с предметной областью.

Тем не менее В.А. Лихошвай любил студентов, отличающихся свободным и бесстрашным взглядом на научные проблемы, и в глубине души верил, что при должном подходе в человеке можно пробудить исследовательскую мысль, отваживающуюся на рассмотрение «больших» проблем. Это достаточно ярко проявлялось, когда во время заседаний кафедры информационной биологии с заслушиванием работ студентов Виталий Александрович, вступая в обсуждение работы кого-то из выступающих, задавал ему или ей вопрос, требующий глубокого осмысления и известной интеллектуальной смелости. Чтобы не быть голословной, приведу один из таких вопросов, застрявших в моей памяти, когда Лихошвай спросил одного студента-математика после его выступления, можно ли считать биологические системы эргодическими. На фоне характерного для подобных отчетных мероприятий пристального внимания к морю частностей подобные вопросы действовали на редкость отрезвляюще и оживляюще, напоминали всем участникам, ради чего все мы здесь собрались.

В целом, должна признать, что для меня оказалось большой честью попасть в орбиту влияния В.А. Лихошвая во времена его активной преподавательской деятельности. Глубина и цельность - вот качества Виталия Александровича, которые служили нам ориентиром, когда мы только входили в область математической биологии, созревали в ней и становились преподавателями сами. Пусть этот небольшой очерк, посвященный памяти В.А. Лихошвая, добавит к его образу выдающегося ученого, блестящего представителя сибирской школы математической биологии, несколько черт, характеризующих его как вдохновляющего учителя, внимательного коллегу и интересного собеседника.

Конфликт интересов. Автор заявляет об отсутствии конфликта интересов.

Поступила в редакцию 09.09.2020. После рецензирования 28.09.2020. Принята к публикации 28.09.2020. 